\title{
Prawo do świadczeń społecznych w encyklice Laborem exercens Jana Pawła II
}

Przedmiotem rozważań niniejszej publikacji są uprawnienia o charakterze społecznym ludzi pracy wynikające z treści Laborem exercens Jana Pawła II. Encyklika ta ma niewątpliwie społeczny charakter, stanowi swoiste kompendium katolickiej nauki społecznej dotyczącej pracy ${ }^{1}$. Jan Paweł II przeprowadził analizę problematyki pracy w odniesieniu do warunków współczesnych ${ }^{2}$, koncentrując się zwłaszcza na ustaleniu źródeł sensu i godności pracy oraz jej aksjologicznej rangi (LE, Wstęp, 9). Encyklika obejmuje rozważania nad wartością pracy, która jest pochwałą celowej i świadomej aktywności człowieka ukierunkowanej m.in. na afirmację osobowości. Osoba jest podmiotem pracy i zarazem jej właściwym i ostatecznym adresatem ${ }^{3}$. Człowiek jako podmiot i sprawca oraz jego praca jako realizacja powołania ludzkiego wraz ze wszystkimi implikacjami życia osobistego, społecznego, moralnego i kulturalnego stanowią przedmiot rozważań w encyklice Laborem exercens.

Papież przypisuje pracy funkcję kreacyjną, widząc w niej środek realizacji pełnego człowieczeństwa. Uwzględniając personalistyczno-moralny charakter pracy ludzkiej, wskazuje, że ma ona swą wartość etyczną, wynikającą z tego,

* Dr Arleta Nerka, Katedra Prawa Pracy, Akademia Leona Koźmińskiego, 03-301 Warszawa, ul. Jagiellońska 57/59.

1 Zob. T. STYCZENं, Osobowa godność podmiotu pracy źródłem jej sensu i wartości, [w:] Ewangelia pracy. Encyklika Jana Pawła II „Laborem exercens” wraz z komentarzem, red. J. Chmiel, S. Ryłka, Kraków 1983, s. 96 i n.; ks. R. KIsIEL, Wokół encyklik Jana Pawła II, „Legnickie Studia Teologiczno-Historyczne" 2002, nr 1, s. 139 i n.

2 J. GaŁKowski, Encyklika o pracy ludzkiej, [w:] Jan PaWEt II, „Laborem exercens”. Tekst i komentarze, red. J. Gałkowski, Lublin 1986, s. 75. Wszystkie cytaty opatrzone skrótem tytułu (LE) pochodzą $\mathrm{z}$ tego wydania.

3 T. STYCZEN, op. cit. 
że wykonuje ją człowiek będący osobą, miarą wartości i sensu pracy ludzkiej (LE 6). Z godności osoby ludzkiej odczytuje się prawa człowieka, których istotną częścią jest ich ochrona. W tym miejscu należy ulokować ideę ubezpieczeń społecznych, realizujących uprawnienia społeczne ludzi pracy, których ostatecznym celem jest ochrona człowieka poprzez umożliwienie realizacji jego praw ${ }^{4}$. Czyniąc Snując refleksje nad wartością pracy w samorealizacji osoby ludzkiej, Autor encykliki stwierdza, że praca stanowi podstawę życia rodzinnego, a w szerszym kontekście również społecznego i narodowego. Istniejący obowiązek pracy implikuje odpowiadające mu uprawnienia człowieka pracy. Praca jest warunkiem zakładania rodziny, realizowania przez nią wszystkich zadań i ważnym czynnikiem kształtującym życie narodu 5 .

\section{Praca jako źródło uprawnień społecznych człowieka}

Jan Paweł II rozpatruje prawa przynależne pracującym w szerokim kontekście ogółu praw właściwych człowiekowi, z których wiele zostało proklamowanych przez organizacje międzynarodowe (m.in. Organizację Narodów Zjednoczonych, Międzynarodową Organizację Pracy, Radę Europy) ${ }^{6}$ i gwarantowanych, przede wszystkim w ustawach zasadniczych, przez poszczególne państwa w stosunku do własnych obywateli ${ }^{7}$. Niewątpliwie wiodący charakter ma tutaj wydana przez ONZ w 1948 r. Powszechna Deklaracja Praw Człowieka, zawierająca w art. 22. stwierdzenie, że „Każdy człowiek ma jako członek społeczeństwa prawo do ubezpieczeń społecznych; ma również prawo do urzeczywistniania - poprzez wysiłek narodowy i współpracę międzynarodową oraz zgodnie z organizacją i zasobami każdego Państwa - swych praw gospodarczych, społecznych i kulturalnych, niezbędnych dla jego godności i swobodnego rozwoju jego osobowości”.

Wypracowanie niekwestionowanych dziś standardów obejmujących prawa społeczne nie byłoby możliwe bez solidarności i współdziałania ludzi pracy skupionych wokół „kwestii robotniczej”. Jan Paweł II stwierdza: „Była to reakcja przeciwko degradacji człowieka jako podmiotu pracy, połączonej z niesłychanym wyzyskiem w dziedzinie zarobków, warunków pracy i troski o osobę pracownika,

4 Tak: R. Rogowskı, Aksjologiczne podstawy ubezpieczeń społecznych, „Annale. Etyka w życiu gospodarczym" 2009, t. 12, nr 1, s. 146; A. SYLWESTRZAK, Filozofia pracy w encyklikach Leona XIII i Jana Pawła II, [w:] Wolność i sprawiedliwość w zatrudnieniu. Księga pamiątkowa poświęcona Prezydentowi Rzeczypospolitej Polskiej Profesorowi Lechowi Kaczyńskiemu, red. M. Seweryński, J. Stelina, Gdańsk 2012, s. 327 i n.

${ }^{5}$ Antropologiczne elementy w encyklice Jana Pawła II "Laborem exercens”, [w:] Jan PAwek II, Laborem exercens. Powołany do pracy, red. J. Krucina, Wrocław 1983, s. 289.

6 Por. Międzynarodowe prawo pracy, „Acta Universitatis Lodziensis” 1981, Folia iuridica 5; Europejskie prawo pracy i ubezpieczeń społecznych, red. L. Florek, Warszawa 1996.

7 Szerzej: M. SADowsKI, Godność człowieka - aksjologiczna podstawa państwa i prawa, http:// www.biblio tekacyfrowa.pl [dostęp: 14.02.2012]. 
która połączyła świat robotniczy we wspólnocie wielkiej solidarności” (LE 8). W konsekwencji ludzie pracy dziś „wywierają wpływ na warunki pracy i wynagrodzenie, jak też na ustawodawstwo społeczne". W ocenie Autora encykliki, społeczna siła pracy polega na jednoczeniu ludzi, a „łączność ludzi dla zabezpieczenia właściwych im uprawnień pozostaje konstruktywnym czynnikiem ładu społecznego i nieodzownej dla tego solidarności" (LE 22). W konsekwencji nieodzownym warunkiem właściwego kształtowania ustawodawstwa społecznego pozostaje solidarność i działanie dla dobra wspólnego. Wyrazem solidarności społecznej jest istnienie ubezpieczeń społecznych rozumianych przez W. Szuberta jako „systemu zagwarantowanych ustawowo i związanych z pracą świadczeń o charakterze roszczeniowym, pokrywającym potrzeby wywołane przez zdarzenia losowe lub inne zrównane $z$ nimi zdarzenia, spełnianych przez zobowiązane do tego instytucje oraz finansowanych na zasadzie bezpośredniego lub pośredniego rozłożenia ciężaru tych świadczeń, w całości lub co najmniej w poważnej mierze, na zbiorowość osób uprawnionych"8.

Idea ubezpieczenia społecznego wyraża pogląd, że społeczeństwo powinno, a nawet ma obowiązek, umożliwić każdemu ze swych członków zaspokojenie w określonym stopniu podstawowych potrzeb. Wartością wpływającą na poziom i jakość życia ludzkiego jest poczucie bezpieczeństwa, które należy do najbardziej fundamentalnych potrzeb egzystencjalnych człowieka. Współcześnie do instrumentów zapewniających budowanie poczucia bezpieczeństwa socjalnego człowieka należy zaliczyć szeroko rozumiane systemy zabezpieczenia społecznego. Odpowiednie ich funkcjonowanie implikuje osiągnięcie gwarancji bezpieczeństwa socjalnego, które jest w polityce społecznej definiowane jako stan wolności od niedostatku materialnych środków utrzymania i istnienia realnych gwarancji pełnego rozwoju jednostki ${ }^{9}$. Zabezpieczenie społeczne pełni szereg zadań, zbieżnych z treściami nauczania Jana Pawła II, do których zalicza się: udzielanie różnego rodzaju świadczeń zapewniających obywatelowi poczucie bezpieczeństwa socjalnego w takich wypadkach, jak: urodzenie i wychowanie dziecka, zagrożenie czy utrata zdrowia, zdarzenia losowe (wraz z działaniami profilaktycznymi i łagodzeniem ich skutków), niezawinione pogorszenie sytuacji materialnej czy utrata możliwości zarobkowania, wygasanie dochodów z pracy, bezradność itp. ${ }^{10}$

Jan Paweł II poszukuje źródeł praw człowieka, a więc i prawa do pracy, bezpośrednio w kategorii godności człowieka ${ }^{11}$. Pisząc o prawach człowieka związanych z pracą, posługuje się takimi sformułowaniami, jak: „uprawnienia ludzi pracy”

\footnotetext{
${ }^{8}$ W. SzUBert, Ubezpieczenia społeczne - zarys sytemu, Warszawa 1987, s. 66.

9 Polityka społeczna, red. A. Rajkiewicz, J. Supińska, M. Księżopolski, Warszawa 1996, s. 247 i n.

10 Polityka społeczna, red. A. Rajkiewicz, Warszawa 1976, s. 433.

11 Jan Pawet II, Redemptor hominis, http://www.opoka.org.pl 14; idem, Nauczanie społeczne 1978-1979, t. 2, Warszawa 1982, s. 316; abp M. Mokrzyckı, Nauczanie społeczne Jana Pawła II w aspekcie praw człowieka, Zamość 2008, s. 7-8.
} 
(LE 18, 20), „prawa człowieka pracy” (LE 1, 17). Prawa te dostrzega i analizuje nie w oderwaniu od innych praw człowieka, ale w kontekście ogółu praw właściwych człowiekowi. Papież stoi na stanowisku, że wszystkie prawa człowieka stanowią jedność, a poszanowanie tych praw jest gwarancją ochrony samego człowieka i utrzymania pokoju.

Wielokrotnie $\mathrm{w}$ literaturze prawa pracy ${ }^{12}$ poddawano analizie sformułowanie encykliki Laborem exercens: „o ile prawdą jest, że człowiek jest przeznaczony i powołany do pracy, to jednak nade wszystko praca jest «dla człowieka», a nie człowiek «dla pracy»" (LE 6), formułując wnioski o podstawowym charakterze prawa do pracy i powinności pracy. „Problem pracy jest kluczem do kwestii społecznej” (LE 3) - to zdanie może stanowić punkt wyjścia rozważań na tematy społeczne.

Praca staje się m.in. narzędziem uzyskiwania dóbr materialnych, będących podstawą egzystowania. W szerszym kontekście dobra materialne są człowiekowi niezbędne do realizacji pełnego człowieczeństwa. Każdy człowiek zatem ma podstawowe prawo do subsystencji (do utrzymywania się) z racji bycia osobą ludzką. Każdy, czyli również osoby upośledzone. Jan Paweł II apeluje do różnych instytucji działających w świecie pracy o popieranie prawa osób upośledzonych do przygotowania zawodowego i do pracy (LE 22), by mogły być włączone w działalność produkcyjną, zgodnie ze swymi kwalifikacjami i możliwościami. Domaga się tego ich godność jako ludzi i jako podmiotów pracy. Papież zwraca uwagę na fizyczne i psychiczne warunki pracy osób upośledzonych, na sprawiedliwe wynagrodzenie, możliwość awansu i usuwaniu przeszkód w życiu codziennym, zawodowym i społecznym. Przedmiotem jego troski było to, żeby właściwe pojmowanie pracy w znaczeniu podmiotowym doprowadziło do sytuacji, w której osoba upośledzona nie czuje się uzależniona od społeczeństwa i zepchnięta na margines życia, może angażować się i wnosić swój wkład w rozwój i dobro własnej rodziny i społeczeństw zgodnie ze swoimi zdolnościami. Byłoby rzeczą w najwyższym stopniu szkodliwą dla człowieka i zaprzeczającą jego człowieczeństwu, gdyby do pracy dopuszczało się wyłącznie osoby pełnosprawne (LE 22).

Konkludując ten wątek, w ujęciu encykliki źródłem uprawnień pracownika jest praca człowieka (LE 16), której - ze względu na jej społeczny charakter - nie można postrzegać jedynie w kategoriach kontraktu zawieranego przez

12 F. Longchamps de Bérier, Jan Paweł ll o prawie do pracy i zabezpieczenia społecznego. W pierwszą rocznicę śmierci, „Praca i Zabezpieczenie Społeczne” 2006, nr 4, s. 5; T. Lıszcz, Papież Jan Paweł II o pracy - w 25 rocznicę ogłoszenia encykliki „Laborem exercens”, „Praca i Zabezpieczenie Społeczne” 2006, nr 10, s. 2 i n.; T. WYKA, Uprawnienia indywidualne i zbiorowe pracowników w świetle nauczania Jana Pawła II, [w:] Praca - dobro indywidualne i społeczne, red. A. Węgrzyniak, T. Bielak, Katowice 2007, s. 35 i n.; eadem, W poszukiwaniu aksjologii prawa pracy - o roli encykliki „Laborem exercens” Jana Pawła II, „Monitor Prawa Pracy” 2011, nr 9, s. 454 i n.; K. WALczAK, Spuścizna Jana Pawła II w zakresie relacji pracowniczych - wyzwania dla rządów i partnerów społecznych, „Monitor Prawa Pracy” 2005, nr 5. 
pracodawcę i pracownika. Szczególnie ważne obowiązki w tej dziedzinie ma - zdaniem papieża - państwo: „To ono bowiem winno prowadzić właściwą politykę pracy" (LE 17). W konsekwencji encyklika rozwija koncepcję pracodawcy bezpośredniego i pośredniego, ale przede wszystkim wskazuje na państwo jako gwaranta prowadzenia odpowiedniej „polityki pracy”. Prawa ludzi pracy, a w tym prawo do zatrudnienia powinno być programem działania społeczno-gospodarczego państwa. „Sprawa posiadania pracy, czyli [...] sprawa odpowiedniego zatrudnienia wszystkich uzdolnionych do tego podmiotów" jest bowiem - zdaniem Jana Pawła II - sprawą podstawową. Zadaniem państwa jest więc przede wszystkim dbałość o to, aby istniało i było realizowane prawo do pracy - aby w prawie tym zagwarantowane były prawa człowieka o niewątpliwie społecznym charakterze.

Pod względem przedmiotowym katalog wspomnianych uprawnień obejmuje: prawo do pracy, prawo do słusznej płacy, prawo zakładania niezależnych związków zawodowych, prawo do strajku, prawo do opieki lekarskiej i świadczeń społecznych ${ }^{13}$. W ich kontekście należy wyróżnić prawa rodziny oraz obowiązek wsparcia dla osób, które nie z własnej winy znajdują się w trudnej sytuacji życiowej i osobistej - niepełnosprawnych, osób żyjących w zapóźnionych cywilizacyjnie obszarach itp.

Uprawnienia społeczne są traktowane jako mierniki sprawiedliwości ustroju społeczno-gospodarczego, które - zdaniem papieża - nabierają ostatecznego kształtu w relacji miedzy pracownikiem a pracodawcą bezpośrednim. W szerszym kontekście można powiedzieć, że świadczenia społeczne są podstawowym elementem systemu zabezpieczenia społecznego, a prawo do nich należy do istotnych uprawnień człowieka w sferze zaspokajania potrzeby bezpieczeństwa socjalnego. Encyklika Laborem exersens buduje koncepcję zabezpieczenia społecznego, której fundamentem jest troska o godność człowieka. Świadczenia społeczne są współcześnie podstawowym dochodem wielu grup społeczno-zawodowych w określonych sytuacjach życiowych związanych z niemożnością osiągania dochodu i determinują warunki materialne życia znacznej części społeczeństwa. Właściwe ukształtowanie uprawnień do nich i poziom świadczeń przesądza o sytuacji pracownika i stanowi podstawowy czynnik gwarantujący godziwy standard życia jego i jego rodziny. Kategoria uprawnień socjalnych należy zatem współcześnie do instrumentów opisujących godność człowieka. W encyklice podkreśla się, że podstawowym czynnikiem warunkującym osobowy rozwój człowieka i kształtowanie materialnych warunków życia jest praca, natomiast świadczenia społeczne stanowią istotne instrumenty o funkcjach wspierających, pomocowych lub zastępczych w stosunku do płacy.

13 Ks. St. KowAlczYK, Z nauczania społeczno-teologicznego Papieża Jana Pawła II, Sandomierz 2004, s. 44 i n. 


\section{Prawo pracownika do społecznej ochrony w razie bezrobocia}

Podstawowym prawem człowieka pracy jest prawo do jej posiadania, czyli prawo do odpowiedniego zatrudnienia wszystkich uzdolnionych do tego podmiotów. Przeciwieństwem właściwej i poprawnej sytuacji w tej dziedzinie jest bezrobocie - brak zatrudnienia dla ludzi zdolnych do pracy, co papież określa mianem „klęski społecznej” (LE 18), zwłaszcza, gdy dotyka ono ludzi młodych, odpowiednio przygotowanych do pracy.

Ogromne zadania spoczywają tutaj na pracodawcy pośrednim, czyli zespole instancji krajowych i międzynarodowych, który powinien przeciwdziałać temu zjawisku na poziomie ogólnym (społecznym), a także indywidualnym. Prawidłowa polityka pracy jest realizowana wówczas, gdy są w niej respektowane obiektywne prawa człowieka pracy. W sytuacji braku pracy potencjalnym pracownikom przysługuje prawo do zabezpieczenia materialnego, czyli prawo do odpowiedniego zasiłku niezbędnego do utrzymania ${ }^{14}$. Obowiązek świadczeń na korzyść bezrobotnych jest powinnością wynikającą z podstawowej zasady porządku moralnego - z prawa do życia i utrzymania.

Obowiązki w zakresie ograniczania i eliminacji bezrobocia oraz pomocy w znalezieniu zatrudnienia dla wszystkich osób zdolnych do pracy Jan Paweł II w encyklice Laborem exercens traktował w kategoriach moralnego obowiązku. Świadczenia społeczne, czyli zasiłki, stanowią jedno z rozwiązań zastępczych, pozwalających tylko w pewnym stopniu na niwelowanie skutków bezrobocia ${ }^{15}$. Zdaniem papieża, zasiłki można uznać za odpowiednie, jeśli pozwalają na utrzymanie niezatrudnionych pracowników oraz ich rodzin. Ich wypłacanie nie jest przejawem dobrej woli: papież wspomina o obowiązku świadczeń dla bezrobotnych - powinności wynikającej z najbardziej podstawowej zasady porządku moralnego w tej dziedzinie, czyli z powszechnego przeznaczania dóbr.

Zadaniem pracodawcy pośredniego jest przeciwdziałać bezrobociu, czuwając nad całościowym planowaniem w odniesieniu do warsztatu pracy, nad prawidłową i celową organizacją pracy (trafna i celowa koordynacja poszczególnych osób, samodzielnych grup i ośrodków). Troska całościowa powinna barkach znajdować się w gestii państwa. Fakt wzajemnego uzależnienia różnych społeczeństw i państw oraz konieczność współpracy w różnych dziedzinach przemawia za tym, by działać równocześnie w wymiarze współpracy międzynarodowej poprzez umowy i porozumienia, których kryterium w coraz większym stopniu ma się stawać praca ludzka. Pokazuje to bezspornie, że kwestia bezrobocia, a zwłaszcza realne warunki jego przezwyciężania, przekracza dziś możliwości poszczególnych państw i wymaga solidarności i koordynacji działań na ponadpaństwowym poziomie.

14 Por. J. KęDzierski, Jan Paweł II - obrońca praw ludzkich, „Palestra” 2011, nr 5-6, s. 17-18.

15 F. Longchamps de Bérier, op. cit., s. 5. 


\section{Troska o dobro rodziny wyznacznikiem ksztaltowania prawa do odpowiedniego wynagradzania}

Z punktu widzenia nauk Jana Pawła II należy spojrzeć na świadczenia społeczne przede wszystkim poprzez pryzmat troski o dobro rodziny. W nauce społecznej Kościoła katolickiego rodzina jest traktowana jako odrębny podmiot praw i obowiązków ${ }^{16}$. „Rodzina bowiem jest czymś więcej niż każdy z osobna człowiek. Jest wspólnotą rodziców i dzieci, bywa niejednokrotnie wspólnotą wielu pokoleń. Dlatego też jej podmiotowość domaga się własnych specyficznych praw"17. W kwestii systemowych działań na rzecz rodziny już J. Piotrowski pisał, że „program działania społecznego na rzecz rodziny jest w dużej mierze programem polityki społecznej w ogóle"18.

Istotną rolę w polityce państwa wobec rodziny odgrywa regulacja stosunków związanych z pracą zawodową, która stanowi - obok życia rodzinnego - najważniejszą sferę egzystencji większości ludzi. Te dwie sfery są ściśle ze sobą powiązane i od siebie zależne, choć w pewnym sensie wobec siebie konkurencyjne ${ }^{19}$. Praca bowiem stanowi podstawę kształtowania życia rodzinnego, które jest naturalnym prawem i powołaniem człowieka. Praca jest warunkiem zakładania rodziny, która domaga się środków utrzymania nabywanych przede wszystkim dzięki pracy. Praca i pracowitość warunkują też proces wychowania w rodzinie, gdyż każdy „staje się człowiekiem” m.in. przez pracę, a to z kolei stanowi istotny cel jest istotnym celem całego procesu wychowania. Rodzina jest równocześnie wspólnotą, która istnieje dzięki pracy i zarazem pierwszą wewnętrzną szkołą pracy dla każdego człowieka. Oprócz przynależności do rodziny, człowiek swoją głębszą tożsamość ludzką łączy z przynależnością do narodu. Swoją pracę pojmuje też jako pomnażanie dobra wspólnego, wypracowanego przez rodaków. Praca służy pomnażaniu dorobku całej rodziny ludzkiej na świecie. W konsekwencji, w rozumieniu encykliki Laborem exercens, rodzina stanowi jeden z najważniejszych układów odniesienia, według których powinien być kształtowany społeczno-etyczny porządek pracy ludzkiej. Dokument ten pozwala zwrócić uwagę na fakt, że rodzina jest wspólnotą, która może istnieć dzięki pracy i jest pierwszą wewnętrzną szkołą pracy dla każdego człowieka. Człowiek powinien pracować zwłaszcza ze względu na rodzinę, ale także ze względu na społeczeństwo, z którym łączą go więzi kultury i historii.

W ujęciu papieża uprawnienia społeczne są traktowane jako element warunkujący właściwe relacje pomiędzy pracą zawodową a życiem rodzinnym. Stanowią

${ }^{16}$ Por. przede wszystkim: Karta Praw Rodziny z 1983 r.; por. również: O rodzinie, seria „Jan Paweł II naucza", Kraków 2011, s. 171 i n.

17 List do rodzin Ojca Świętego Jana Pawła II, za: T. Lıszcz, Prawo pracy instrumentem polityki prorodzinnej państwa, „Praca i Zabezpieczenie Społeczne” 2007, nr 6, s. 2-3.

18 J. Piotrowski, Zabezpieczenie społeczne. Problematyka i metody, Warszawa 1966, s. 363.

19 T. Liszcz, Prawo pracy..., s. 3. 
one konieczne ogniwo pozwalające na rozwój rodziny, macierzyństwa i rodzicielstwa przy jednoczesnej samorealizacji jej członków w różnych aspektach życia rodzinnego, zawodowego, społecznego. Praca przyczynia się wraz z kapitałem do generowania zysków przedsiębiorstwa, w których zawierają się owoce pracy, albowiem „płaca jest wyrazem prawa robotnika do owoców jego pracy”20.

W kategorii uprawnień papież przypisuje największe znaczenie płacy rodzinnej, czyli wynagrodzeniu danemu głowie rodziny za pracę, wystarczającemu na zaspokojenie potrzeb rodziny bez konieczności podejmowania pracy zarobkowej poza domem przez współmałżonka, czy to poprzez inne świadczenia społeczne, jak zasiłek rodzinny albo dodatek macierzyński dla kobiety, która oddaje się wyłącznie rodzinie; dodatek ten powinien odpowiadać realnym potrzebom, to znaczy uwzględniać liczbę osób pozostających na utrzymaniu w ciągu całego okresu, gdy nie są w stanie podjąć odpowiedzialności za własne życie. Problemem kluczowym etyki społecznej, który Jan Paweł II również porusza, jest sprawa sprawiedliwej zapłaty za wykonywaną pracę ${ }^{21}$. Sprawiedliwa płaca staje się sprawdzianem sprawiedliwości całego ustroju społeczno-ekonomicznego, który dotyczy przede wszystkim rodziny. Płaca sprawiedliwa to ta, która wystarcza na założenie i godziwe utrzymanie rodziny oraz na zabezpieczenie jej przyszłości. Wynagrodzenie to może być realizowane przez tzw. płacę rodzinną lub przez inne świadczenia społeczne, np. zasiłek rodzinny, dodatek macierzyński - powinno uwzględniać realne potrzeby.

\section{Uprawnienia społeczne $z$ tytułu wypełniania funkcji macierzyńskich i rodzicielskich}

W zakresie wskazania uprawnień do świadczeń społecznych, obok płacy rodzinnej, papież zwrócił uwagę na świadczenia o innym charakterze, które współcześnie są związane w większym lub mniejszym stopniu z wykonywaniem pracy. Należy tutaj wymienić uprawnienia związane z macierzyństwem i rodzicielstwem, a zaliczono do nich m.in.: „zasiłek rodzinny albo dodatek macierzyński dla kobiety, która oddaje się wyłącznie rodzinie”. Z punktu widzenia systemów społecznych systemy zasiłków rodzinnych i macierzyńskich służą zmniejszaniu różnic wynikających ze stanu rodzinnego poprzez odpowiednią korektę podziału dochodu oraz zaspokajaniu zwiększonych, długotrwałych potrzeb rodziny ${ }^{22}$. W przekonaniu Jana Pawła II świadczenia te stanowią element płacy rodzinnej, pozwalając na właściwą realizację funkcji płacy. Papież nie tylko wskazuje na prawo do tych

20 Por. J. Wratny, Obowiązek pracy. Prawo do pracy oraz uprawnienia człowieka pracującego, „Chrześcijanin w Świecie” 1984, nr 3 (16), s. 25-40.

21 T. Liszcz, Prawo pracy..., s. 6 i n.

22 W. SzUBert, op. cit., s. 119 i n. 
świadczeń, lecz także odnosi się do ich wysokości - dodatek ten powinien odpowiadać realnym potrzebom, tzn. uwzględniać liczbę osób pozostających na utrzymaniu w ciągu całego okresu, gdy nie są w stanie podjąć odpowiedzialności za własne życie. Wysokość świadczeń bez wątpienia powinna odpowiadać zabezpieczeniu poziomu życia odpowiadającego godności człowieka.

Zabezpieczenie materialne w okresie macierzyństwa nie jest jednakże jedyną troską Jana Pawła II. Wiele uwagi poświęcił potrzebie starań „o społeczne dowartościowanie zadań macierzyńskich". Przede wszystkim chodzi o stworzenie kobiecie realnego wyboru i uszanowanie jej troski o wychowanie dzieci. „Doświadczenie potwierdza, że należy starać się o społeczne dowartościowanie zadań macierzyńskich, trudu, jaki jest z nimi związany, troski, miłości i uczucia, których dzieci nieodzownie potrzebują, aby mogły się rozwijać jako osoby odpowiedzialne, moralnie i religijnie dojrzałe oraz psychicznie zrównoważone" (LE 19). Zdaniem papieża należy tak zorganizować życie społeczne, aby nie ograniczać wolności matki, nie dyskryminować jej psychologicznie lub praktycznie, nie pogarszać jej sytuacji w zestawieniu z innymi kobietami, umożliwić jej oddanie się trosce o wychowanie dzieci odpowiednio do zróżnicowanych potrzeb ich wieku. Zaniedbanie funkcji macierzyńskich z powodu konieczności pracy zarobkowej jest niewłaściwe z punktu widzenia dobra społeczeństwa i rodzinny, ponieważ utrudnia wypełnianie najważniejszych celów macierzyństwa. Cały system pracy trzeba tak organizować i dostosowywać, by były uszanowane wymogi osoby i formy jej życia, z uwzględnieniem wieku i płci. Kobiety nie powinny być dyskryminowane i pozbawiane możliwości podjęcia pracy, do jakiej są zdolne ${ }^{23}$. Szeroko rozpowszechniona tradycja społeczna i kulturalna przyznawała kobiecie jedynie rolę małżonki i matki, nie umożliwiając jej odpowiedniego dostępu do zadań społecznych, zarezerwowanych na ogół dla mężczyzny. Nie ulega wątpliwości, że równa godność i odpowiedzialność mężczyzny i kobiety usprawiedliwia w pełni dostęp do zadań publicznych. $Z$ drugiej strony prawdziwy awans kobiety domaga się także, by wyraźnie została uznana wartość jej zadań macierzyńskich i rodzinnych w odniesieniu do wszystkich zadań publicznych i wszystkich innych zawodów.

Właściwe kształtowanie płacy rodzinnej pozwoli na odpowiednią opiekę nad dziećmi, co procentuje dla dobra rodziny i społeczeństwa. Jednakże realizacja obowiązków macierzyńskich nie może spowodować pogorszenia sytuacji kobiety, prowadzić do jej dyskryminacji lub wykluczenia. Przyniesie to chlubę społeczeństwu, jeśli — nie ograniczając wolności matki, nie dyskryminując jej psychologicznie lub praktycznie, nie pogarszając jej sytuacji w zestawieniu z innymi kobietami - umożliwi kobiecie-matce oddanie się trosce o wychowanie dzieci, odpowiednio do zróżnicowanych potrzeb ich wieku. Zaniedbanie tych obowiązków spowodowane koniecznością podjęcia pracy zarobkowej poza domem jest niewłaściwe z punktu widzenia dobra społeczeństwa i rodziny, skoro uniemożliwia lub utrudnia wypełnienie pierwszorzędnych celów posłannictwa macierzyńskiego (LE 19).

${ }^{23}$ O rodzinie..., s. $135 \mathrm{i} \mathrm{n}$. 


\section{Uprawnienia w sferze ochrony zdrowia pracownika i członków jego rodziny}

Jan Paweł II wskazuje na konieczność zapewnienia różnych świadczeń społecznych, służących zabezpieczeniu życia i zdrowia pracowników i ich rodzin. Szczególną uwagę poświecono wydatkom związanym z koniecznością leczenia, zwłaszcza w razie wypadku przy pracy, posiadanie przez pracownika ułatwionego kontaktu z ośrodkami pomocy lekarskiej — i to, w miarę możliwości, kontaktu taniego, a nawet bezpłatnego (LE 19). Uprawnienia te można zaklasyfikować jako prawo do ochrony zdrowia.

$Z$ pracą sprzężony jest korelatywnie odpoczynek, co odzwierciedla właściwe ustawienie relacji między pracą a czasem wolnym. Odpoczynek można oceniać nie tylko jako ochronę czasu przeznaczonego na życie osobiste i rodzinne pracownika ${ }^{24}$, lecz także jako element ochrony zdrowia pracownika. Papież podkreśla, że pracownik ma prawo do wypoczynku, przynajmniej w niedzielę, oraz prawo do urlopu.

\section{Potrzeba ochrony społecznej pracowników w razie starości i niemożności zarobkowania}

Istotnym elementem zespołu uprawnień społecznych ludzi pracy jest prawo do emerytury, zabezpieczenia na starość i w razie wypadków związanych z rodzajem wykonywanej pracy (LE 19). Wśród wskazanych uprawnień zasadnicze znaczenie mają uprawnienia emerytalne związane ze stanem niemożności zarobkowania. Ze względu na ich społeczny wymiar i funkcje, stanowią podstawowe źródło dochodu na starość, wypracowanego w okresie aktywności zawodowej. Stąd należy zapewnić zaspokojenie potrzeb ludzi pracy na czas zasłużonego odpoczynku, po osiągnięciu wieku emerytalnego lub niemożności dalszego zarobkowania z powodu upadku sił zawodowych, na poziomie odpowiadającym godności osoby ludzkiej. Encyklika Laborem exercens nie ogranicza się jedynie do wskazania konieczności zagwarantowania uprawnień do świadczeń pieniężnych, wspomina o kształtowaniu więzi społecznych w duchu etyki społecznej. W polityce społecznej podkreśla się, że działania na rzecz osób starszych powinny uwzględniać przede wszystkim ich ludzką godność. Stosunek do starego człowieka jest miarą humanistycznych stosunków w społeczeństwie ${ }^{25}$ i świadczy o jego poziomie cywi-

24 T. Liszcz, Prawo pracy..., s. 8.

25 J. Auleytner, Polska polityka społeczna. Kreowanie ładu społecznego, Warszawa 2005 , s. $160 \mathrm{i} \mathrm{n}$ 
lizacyjnym. Elementem prowadzonej polityki społecznej pozostaje kształtowanie systemów zabezpieczenia społecznego w takim kierunku, aby gwarantowały materialne zabezpieczenie życia osoby ludzkiej na odpowiednim poziomie.

W obrębie uprawnień społecznych Jan Paweł II wskazuje system uprawnień szczegółowych, które regulują prawidłowe stosunki między pracownikiem a pracodawcą, np. by miejsce pracy i procesy produkcji nie szkodziły zdrowiu fizycznemu i moralnemu. Podejmując ten wątek, należy rozważyć kwestię niebezpieczeństw, które niesie dla zdrowia i życia pracownika wykonywana praca ${ }^{26}$. Trudno uznać, by ryzyko utraty zdrowia lub życia w całości obciążało pracownika, zatem zgodnie z zasadami etyki społecznej powinno rozkładać się na pracowników, pracodawców i państwo. Stąd już blisko do idei urządzeń społecznych, które pełnią funkcje osłonowe; ich celem jest zapobieganie biedzie, zwłaszcza o losowym i niezawinionym charakterze. Ludzie niemogący pracować nie powinni bowiem pozostać bez środków do życia, wynika stąd potrzeba istnienia zabezpieczenia społecznego ${ }^{27}$.

\section{Zakończenie}

Trudno wyobrazić sobie lepsze aksjologiczne fundamenty budowania koncepcji zabezpieczenia społecznego niż odwołanie się do godności człowieka i praw z niej wypływających. Uogólniając można stwierdzić, że Jan Paweł II wskazuje wprost na ścisły związek prawa do zabezpieczenia społecznego z absolutnie podstawowym prawem do życia i utrzymania (LE 19). Uprawnienia do świadczeń społecznych, składające się na prawo do zabezpieczenia społecznego (uprawnienia główne i szczegółowe), stanowią w pewnym sensie postulaty pod adresem polityki państwa. Jak wskazują doświadczenia, ich realizacja niejednokrotnie jest zależna od uwarunkowań politycznych, społecznych, kulturowych, a przede wszystkim możliwości ekonomicznych. Nie bez znaczenia jest poczucie wspólnoty, odpowiedzialności i solidarności w społeczeństwie, do czego nawoływał Jan Paweł II. Z papieskiego nauczania przebija bowiem głęboka nadzieja, że podmiotowy i przedmiotowy wymiar pracy będzie prowadzić do rozwijania w każdym pracowniku człowieczeństwa przez właściwe układanie stosunków między pracownikiem a pracodawcą bezpośrednim. Można to również przenieść na stosunki między obywatelem (pracownikiem) a pracodawcą pośrednim, od którego w głównej mierze zależy kształtowanie uprawnień społecznych ludzi pracy, zwłaszcza po zakończeniu wykonywania pracy zarobkowej.

${ }^{26}$ Por. szerzej: T. WYKA, op. cit., s. 36 i n., przyp. 12.

27 J. MaJKa, Etyka życia gospodarczego, Wrocław 1982, wyd. 2, s. 174 i n. Por. Jan PaWek II, Przemówienie na 68 Sesji Specjalnej Zgromadzenia Ogólnego ONZ (15 czerwca 1982 r.), [w:] Dokumenty nauki społecznej Kościoła, red. M. Radwan, L. Dyczewski, A. Stanowski, Rzym-Lublin 1987, nr 11. 
Funkcją zabezpieczenia społecznego jest przede wszystkim ochrona człowieka w określonych sytuacjach życiowych uniemożliwiających wykonywanie pracy, które rodzą potrzebę posiadania innych źródeł utrzymania. Wpisuje się to $w$ idee ochrony najsłabszych ekonomicznie jednostek, jest związane $z$ doktryną państwa opiekuńczego, w którym państwo przejmuje zagwarantowanie bezpieczeństwa socjalnego ogółowi obywateli, a w szczególności osobom najbiedniejszym ${ }^{28}$. Świadczenia społeczne jako uzasadniony dochód zastępczy, chronią przed marginalizacją, czyli wyłączeniem poza obręb życia społecznego i kulturalnego. Pracownicy bowiem w okresie aktywności zawodowej przyczyniają się do zwiększenia majątku narodowego, unowocześnienia gospodarki, usprawnień techniczno-informatycznych, zdobycia kwalifikacji przez obecnie zatrudnionych, stwarzając w ten sposób materialne i organizacyjne podstawy wytworzenia środków na pokrycie świadczeń ubezpieczeniowych w przyszłości.

${ }^{28}$ M. RYMSzA, Solidaryzm w ubezpieczeniach społecznych, [w:] Społeczne aspekty ubezpieczenia, red. T. Szumlicz, Warszawa 2005, s. 50-51. 